\title{
Endoscopic ultrasound-assisted endoscopic resection of carcinoid tumors of the gastrointestinal tract
}

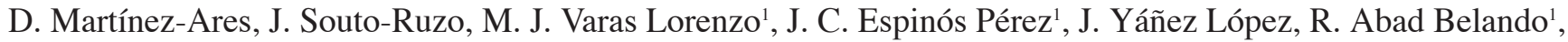 \\ P. A. Alonso Aguirre, J. M. Miquel Colell ${ }^{1}$ and J. L. Vázquez Iglesias
}

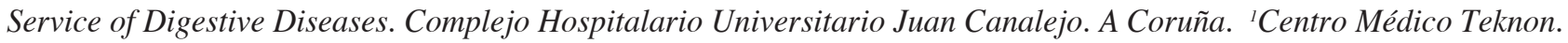
Barcelona. Spain

Martínez-Ares D, Souto-Ruzo J, Varas Lorenzo MJ, Espinós Pérez JC, Yánez López J, Abad Belando R, Alonso Aguirre PA, Miquel Colell JM, Vázquez Iglesias JL. Endoscopic ultrasound-assisted endoscopic resection of carcinoid tumors of the gastrointestinal tract. Rev Esp Enferm Dig 2004; 96: 847-855.

\begin{abstract}
Introduction: usually found in the gastrointestinal tract, carcinoids are the most frequent neuroendocrine tumors. Most of these lesions are located in areas that are difficult to access using conventional endoscopy (small intestine and appendix); carcinoid tumors found in the gastroduodenal tract and in the large intestine can be studied endoscopically; in these cases, if localized disease is confirmed, local treatment by endoscopic resection may be the treatment of choice. Since endoscopic ultrasonography has been shown to be the technique of choice for the study of tumors exhibiting submucosal growth, the selection of patients who are candidates for a safe and effective local resection should be based on this technique.

Patients and method: we selected patients with gastrointestinal carcinoid tumors who were endoscopically treated between 1997 and 2002. Those patients with tumors measuring less than $10 \mathrm{~mm}$, which had not penetrated the muscularis propria, and those with localized disease were considered candidates for endoscopic resection. The endpoints of this study were to assess the effectiveness (complete resection) and safety (complications) of the technique. Follow-up consisted of eschar biopsies performed one month and twelve months after the resection.

Results: during the aforementioned period, we resected endoscopically 24 tumors in 21 patients (mean age: 51.7 years; $71.5 \%$ males). Most lesions were incidental discoveries made during examinations indicated for other reasons. Resection was indicated in most cases as a result of the suspected presence of a carcinoid tumor after endoscopic ultrasonography. Endoscopic
\end{abstract}

Recibido: 23-03-04.

Aceptado: 11-05-04.

Correspondencia: David Martínez Ares. C/ Alcalde Gregorio Espino, 77, $5^{\circ}$ B. 36205 Vigo. Pontevedra. Telf.: 981128 914. e-mail: martinezares7@hotmail.com ultrasonography also enabled us to clearly identify the layer where the lesion had originated, as well as the size of the lesion. The carcinoid tumor was removed in 13 cases (54.2\%) by using the conventional snare polypectomy technique, in 9 cases (37.5\%) assisted by a submucosal injection of saline solution and/or adrenaline, and in 2 cases (8.3\%) after ligating the lesion with elastic bands. In all cases the resection was complete, with no recurrence during the follow-up period, and no major complications, except for a single case in which a post-polypectomy hemorrhage occurred that was endoscopically solved.

Conclusions: in properly selected patients, the endoscopic resection of carcinoid tumors is a safe and effective technique that permits a complete resection in all cases with few complications. Endoscopic ultrasonography is the technique of choice for selecting the patients who are candidates for endoscopic resection.

Key words: Carcinoid tumors. Management. Endoscopic resection. Complications. Endoscopic ultrasonography.

\section{INTRODUCTION}

Carcinoid is the most frequent neuroendocrine tumor (1), with an annual incidence of 2-2.4 cases per 100,000 inhabitants; $74 \%$ of these tumors arise in the digestive tract (2); their most common locations are the small intestine and the appendix $(1,2)$, having the latter the best prognosis (2).

Only carcinoids located in the gastroduodenal area $(3 \%$ of total) as well as those located in the colon and rectum (10 and $11 \%$, respectively) are accessible to endoscopic study (2). Local resection is only considered in cases of localized disease. Thus, type 1 and 2 gastric carcinoids less than 10 $\mathrm{mm}$ in diameter (fewer than $2 \%$ are metastatic) can be endoscopically removed. On the other hand, tumors located in the colon, usually in the right colon and slightly symptomatic, are diagnosed in more advanced phases (3). In the rectum, up to $85 \%$ are found when diagnostic tests are performed for other reasons, and therefore are incidental findings. Like gastric carcinoids, fewer than $2 \%$ of rectal tumors with a diameter below $1 \mathrm{~cm}$ are metastatic, in contrast with 
$60-80 \%$ of those measuring more than $2 \mathrm{~cm}(4,5)$. In addition, when endoscopic ultrasound (EUS) shows that the muscular layer remains unscathed $(4,6)$, local treatment can be safely and effectively applied. When the size of the tumor ranges from 1 to $2 \mathrm{~cm}$, the decision regarding what therapeutic attitude to adopt can be difficult. It is estimated that $10-15 \%$ of tumors have metastases (7), which imply that the treatment of choice will depend on the patient's surgical risk. Only in patients with unassumable risk will local treatment be applied (8).

Carcinoids are submucosal tumors, with growth in any of the layers of the wall of the gastrointestinal tract underneath a tumor-free mucosa (9). They originate in cells of the gastrointestinal stroma (10). Most carcinoids are discovered incidentally during examinations indicated for other reasons (11). Conventional endoscopy is greatly limited in the diagnosis of submucosal tumors, as endoscopic biopsies are rarely conclusive $(9,11,12)$. Furthermore, cytology samples taken from these lesions by fine-needle aspiration (FNA) are not very profitable (11,13-16). In addition, the diagnosis of malignancy is based on a series of parameters that, in many cases, can only be studied on examining resected tissue (17).

Endoscopic resection of submucosal tumors has been shown to be a safe, effective technique (18-22) that is clearly superior to endoscopic biopsy in these cases (23). Since removal is the most appropriate way to reach a diagnosis in this type of lesion, tumors will have to be removed whenever the lesion reaches a large size, shows significant growth, becomes complicated by obstructive symptoms or bleeding, and if diagnostic doubts exist $(11,24)$.

EUS is the technique of choice for the study of these lesions conducted prior to resection $(11,25,26)$. In fact, it enables the physician to precisely differentiate submucosal tumors from extrinsic compressions $(11,19,29-31)$, and solid masses from cystic lesions (9); moreover, it evaluates the layer where the tumor originated with a high degree of precision (24,32), as well as the tumor's size (27). In addition, it may preoperatively establish the type of lesion involved $(11,24,34-37)$, and has proven highly accuracy in predicting malignant behavior $(26,28,29,38)$.

In this study we will discuss our results in the EUS-assisted endoscopic resection of carcinoid tumors. The objective of this paper is to show how EUS makes it possible to select patients that will benefit from local treatment, since a correct evaluation of the size and tumor-originating tissue layer ensures a complete and safe resection in most cases.

\section{PATIENTS AND METHOD}

\section{Patient selection}

Patients having undergone endoscopic resection for gastrointestinal carcinoids between January $1^{\text {st }}, 1997$ and December 31"st, 2002 at "Juan Canalejo" Hospital, A Coruña, and "Centro Médico Teknon", Barcelona, Spain, were selected. Patients were subsequently subjected to prospective follow-up, which included only those who were subject to a minimum follow-up of 12 months.

\section{Methodology}

All patients in whom a digestive submucosal lesion was identified underwent an echoendoscopic study using an Olympus GF-UM 160 radial scanning echogastrofiberscope and an Olympus CF-UM 20 echocolonoscope. When this examination defined a lesion considered suitable for resection, an endoscopic resection was performed using the Olympus GIF-100 and Olympus GIF 120 gastroscopes, or an Olympus GIF 100 colonoscope. The resection was accomplished with a polypectomy snare by applying three different techniques: the conventional snare polypectomy technique, a resection assisted by the submucosal injection of physiological saline solution and/or diluted adrenaline, or a resection assisted by ligation with elastic bands to ensure a correct elevation of the lesion. Before proceeding with the resection, a distribution study was conducted by means of an abdominopelvic CT scan, a test for urinary 5-hydroxyindoleacetic acid, or an octreotide scintigraphy.

Patients considered suitable for endoscopic resection were those with tumors measuring less than $1 \mathrm{~cm}$ in diameter in whom an endoscopic ultrasonography had shown that the fourth layer (the muscularis propria) had not been affected by the tumor, and those in whom extension studies ruled out distant spread. Some patients who exhibited excessive surgical risk, who had larger tumors even with still localized disease, were also subjected to endoscopic resection. Finally, after resection, follow-up was scheduled as consisting of eschar biopsies at one and twelve months after tumor removal.

\section{Variables studied}

In addition to demographic data, the study included all the variables related to the endoscopic and echoendoscopic characteristics of the lesions (size, morphology, edge appearance, echogenicity, presence of cystic areas or hyperechogenic foci, presence of adenopathies, ulcerations, and layer in which the tumors were found). Similarly, we made a detailed study of the location of lesions, clinical manifestations derived from them, reason why resection was indicated, and resection technique used. Logically, the primary endpoint of the study was to evaluate the effectiveness of endoscopic resection for submucosal tumors (completeness of resection) and the safety of this technique (presence and nature of complications). For the statistical analysis, we used the SPSS 11.5 statistical software package for Windows.

\section{RESULTS}

During the study period, 24 carcinoid tumors were treated endoscopically in 21 patients (19 patients with single tumors, two with multicentric tumors). Patient mean age was 51.76 years (range, 31 to 73 ), and the majority of patients were males $(71.5 \%)$.

The majority of tumors were gastric lesions $(41.7 \%)$ or rectal lesions $(41.7 \%)$. The remaining lesions were located 
in the duodenum $(16.6 \%)$. In most cases $(71.5 \%)$, tumors were incidental findings arising during examinations indicated for other reasons (Table I).

\section{Table I}

\begin{tabular}{|c|c|}
\hline Variables & $\begin{array}{c}\text { Number of patients } \\
\text { (\%) }\end{array}$ \\
\hline Patients & 21 \\
\hline Resected tumors & 24 \\
\hline Patients with multicenter tumors & $2(9.5 \%)$ \\
\hline $\begin{array}{l}\text { Distribution by sex } \\
\text { Men } \\
\text { Women }\end{array}$ & $\begin{array}{r}15(71.5 \%) \\
6(28.5 \%)\end{array}$ \\
\hline $\begin{array}{l}\text { Location of lesions } \\
\text { Stomach } \\
\text { Rectum } \\
\text { Duodenum }\end{array}$ & $\begin{array}{r}10(41.7 \%) \\
10(41.7 \%) \\
4(16.6 \%)\end{array}$ \\
\hline $\begin{array}{l}\text { Size of lesions } \\
\quad<10 \mathrm{~mm} \\
10-20 \mathrm{~mm} \\
>20 \mathrm{~mm}\end{array}$ & $\begin{array}{c}20(83.2 \%) \\
3(12.6 \%) \\
1(4.2 \%)\end{array}$ \\
\hline $\begin{array}{l}\text { Clinical manifestations } \\
\text { Dyspepsia } \\
\text { Upper gastrointestinal bleeding } \\
\text { Lower gastrointestinal bleeding } \\
\text { Anemia } \\
\text { Incidental discovery }\end{array}$ & $\begin{array}{c}2(9.4 \%) \\
1(4.7 \%) \\
1(4.7 \%) \\
2(4.7 \%) \\
15(71.5 \%)\end{array}$ \\
\hline $\begin{array}{l}\text { Resection indications } \\
\text { Malignancy in biopsies } \\
\text { Suspicion of carcinoid } \\
\text { Bleeding }\end{array}$ & $\begin{array}{c}5(20.8 \%) \\
18(75 \%) \\
1(4.2 \%)\end{array}$ \\
\hline $\begin{array}{l}\text { Resection technique } \\
\text { Polypectomy with submucosal injection } \\
\text { Conventional snare polypectomy } \\
\text { Band-assisted polypectomy }\end{array}$ & $\begin{aligned} 9 & (37.5 \%) \\
13 & (54.2 \%) \\
2 & (8.3 \%)\end{aligned}$ \\
\hline Complete resection & $24(100 \%)$ \\
\hline $\begin{array}{l}\text { Complications } \\
\text { Bleeding } \\
\text { Perforation }\end{array}$ & $\begin{array}{l}1(4.2 \%) \\
0\end{array}$ \\
\hline
\end{tabular}

The average size of the lesions measured by conventional endoscopy was $8 \mathrm{~mm}$, significantly smaller $(\mathrm{p}=0.02)$ than the size of the resection piece $(9 \mathrm{~mm})$. However, the average size measured by EUS was $8.95 \mathrm{~mm}$, with no significant differences with respect to the size measured by a pathologist ( $p=0.25$ ). In all, $83.2 \%$ of lesions (20 tumors) measured less than $10 \mathrm{~mm}$, three lesions measured between 10 and 20 $\mathrm{mm}$, and only one was greater than $20 \mathrm{~mm}$. In all cases, localized disease was confirmed; in patients with lesions larger than $10 \mathrm{~mm}$, surgical risk from associated diseases was too high.

In all of the cases, lesions depended from the muscularis mисоsae, had regular edges, were hypoechogenic, and had homogeneous echographic pattern (Fig. 1). In only one case, the tumor was ulcerated and was the cause of digestive

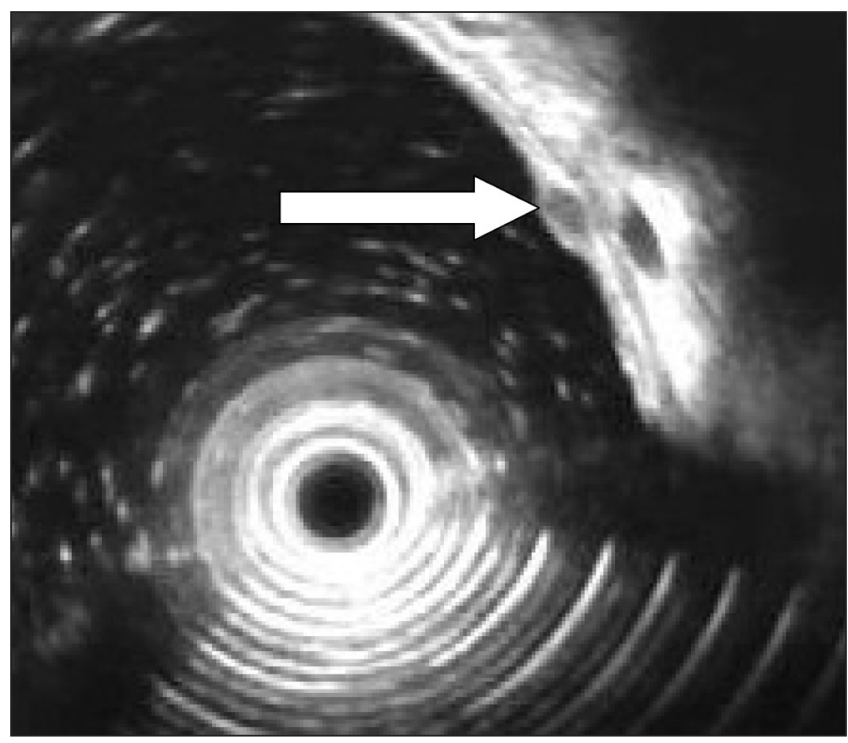

Fig. 1.- A hypoechogenic lesion may be observed in this image. The lesion is dependent on the second layer, and has regular edges and a homogeneous echographic pattern (white arrow).

En la imagen se observa una lesión hipoecogénica, dependiente de la segunda capa, de bordes regulares y con un patrón ecográfico homogéneo (flecha blanca).

bleeding. A resection of submucosal lesions was indicated in 18 cases $(75 \%)$ following suspicion of a carcinoid tumor as arisen by ultrasonography, in five cases (20.8\%) by biopsies suggesting malignancy, and in another case by tumorrelated bleeding (Table I).

In 13 cases (54.2\%), the resection was performed using the conventional snare polypectomy technique; in 9 cases $(37.5 \%)$, the resection was preceded by injection of physiological saline and/or adrenaline to achieve better elevation of the lesion; and finally, in 2 cases $(8.3 \%)$ the resection was done after ligating the lesion with elastic bands (Fig. 2). Latter cases involved very small lesions measuring 5 and $6 \mathrm{~mm}$ that could not be properly elevated by submucosal injection.

In all cases, the resection was complete; this result was documented by examining the resection piece, which showed tumor-free edges; furthermore, biopsies performed 30 days and 12 months after resection ruled out local recurrence in all cases. Only one important complication arose: a significant hemorrhage that was controlled endoscopically. The patient was hospitalized for observation, and did not require blood transfusion.

\section{DISCUSSION}

Endoscopic resection of carcinoid tumors is not a new technique; it has been used since the 1990s. In 1997, Higaki et al. (39) published a series of 22 rectal carcinoids, 18 of which were endoscopically resected. The authors showed that when a tumor was less than $10 \mathrm{~mm}$ in diameter and did not invade tissue beyond the submucosa (muscularis propria spared), the risk of distant spread was minimal, which indicated that, in such cases, local endoscopic resection was 


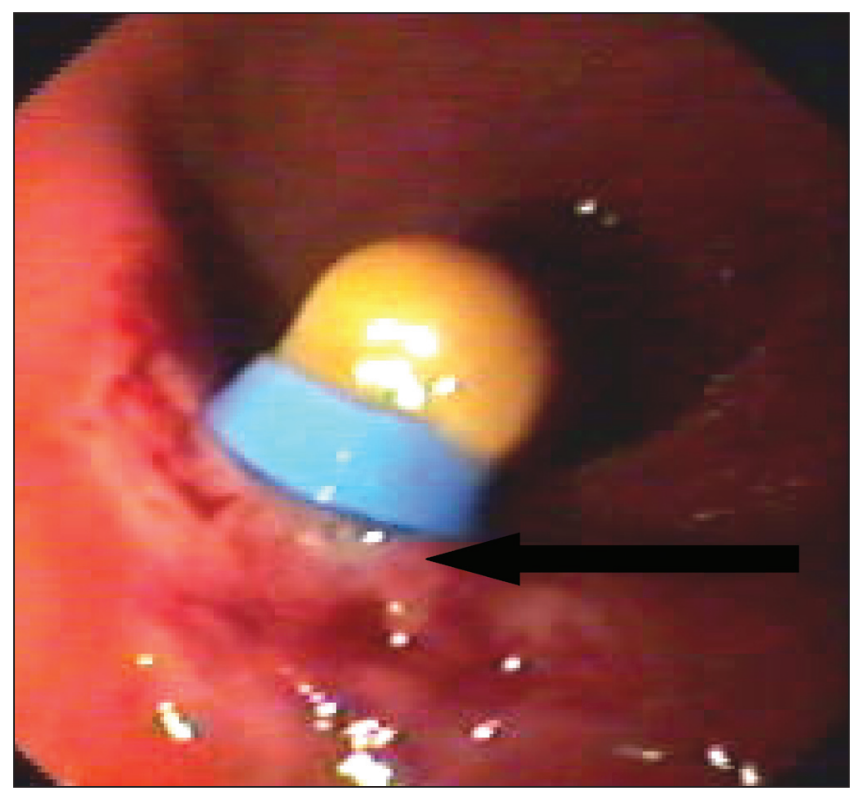

Fig. 2.- The lesion shown here (black arrow) is elevated after ligation with an elastic band.

Se observa (flecha negra) la lesión sobreelevada tras ser ligada con una banda elástica.

a valid alternative. We have followed these criteria to indicate an endoscopic resection in lesions of this nature: lesions having a diameter less than $10 \mathrm{~mm}$, with evidence of local disease, and a tumor-free muscular layer. Only four larger lesions were endoscopically resected; in all cases, the extension study was negative, and the high surgical risk made local resection the most suitable procedure. Also in 1997, Imada-Shirakata et al. (40), and more recently Oshitani et al. (41), reached the same conclusions, albeit with a series of only 8 and 7 patients, respectively. Both the size of the tumor and the wall layer in which it is located can be established with high accuracy using EUS; this is also true for the rest of submucosal tumors $(26,27,32)$. In our experience, EUS enabled us to successfully establish the origin layer in all cases, and to evaluate very precisely the size of the tumor. On the other hand, conventional endoscopy underestimates lesion size as it can only evaluate intraluminal growth.

From an ultrasonographic standpoint, the morphology of carcinoid tumors is quite similar to that of leiomyomas: well-delimited, hypoechoic lesions with homogeneous echogenicity, regular edges, and located in the first three layers of the intestinal wall (11). Thus, in many cases, resection is the only way to reach a diagnosis. However, the endoscopic resection of submucosal lesions has a well-documented complication rate, being the bleeding the most common of them. Its frequency varies from 4.8 to $16 \%$ (2023 ), and it was endoscopically solved in all reported cases, with no need for surgery. Only one major complication occurred in our series (1 case of bleeding controlled endoscopically); it must be borne in mind that nearly all of the lesions were located in the gastric cavity and in the rectum, where the frequency of complications is significantly less than in the right colon or even the duodenum. EUS is the most suitable technique for evaluating size of tumors and their exact location in the inner wall of the gastrointestinal tract, and even to venture an opinion on the lesion's nature. Additionally, some authors have also used ultrasonography to show the correct elevation of lesions after submucosal injection of various substances (41). In contrast, Lachter et al. (43) stated that endoscopic ultrasonography may have a limited value because, in their experience, a prior echoendoscopic study does not exclude subsequent follow-up and resection margins were infiltrated by the tumor in all their cases. However, their experience is limited to only three tumors, and their article mentions some other important aspects of EUS, such as its ability to exclude the presence of vascular structures near the lesion that otherwise would markedly increase the risk of hemorrhage. Consequently, even if the first of their statements is accepted, the second would concede an enormous value to EUS-assisted endoscopic resection of submucosal tumors.

Different techniques have been described for carcinoid tumor resection. Resection may be performed by using the conventional snare polypectomy technique, but some authors prefer a previous elevation of the lesion by means of submucosal injection of various substances, such as physiological saline, diluted adrenaline, etc. $(42,44)$. Other authors have described a technique involving aspiration of the lesion into a cap, as in elastic band ligation, which would facilitate the grasping of the lesion with a polypectomy snare $(40,41)$. Some physicians have proposed elevation of the lesions by ligating them with elastic bands to ease their removal using a polypectomy snare (45-48). Kajiyama et al. (47) reported that the use of the aspiration method, either with elastic band ligation or a cap, is clearly more effective than the strip biopsy method; they indicated that aspiration ensures diagnosis in $95 \%$ of cases, compared to $77 \%$ with strip biopsy, and that a complete resection of the lesion is achieved in $87 \%$ of cases involving aspiration, compared to $74 \%$ for strip biopsy. Recently, Ono et al. (48) published a study in which they compared two resection techniques. They described a series of 14 rectal carcinoid tumors resected using an elastic band-assisted resection technique, achieving complete resection in $100 \%$ of cases. These results were compared with those of a retrospective series of 14 cases resected using a conventional snare polypectomy technique or a mucosectomy technique, in which resection margins were affected in $42 \%$ of cases. Differences exist even within this group, since surgical margins were affected less frequently in patients undergoing mucosectomy. These findings differ markedly from the results in our series. In 13 cases, we employed a snare polypectomy technique, in nine a resection assisted by submucosal injection of physiological saline and/or diluted adrenaline, and in two cases a resection assisted by elastic bands. The resection was complete in $100 \%$ of cases, and in no case did we observe local or distant recurrences (all extension studies had also been negative). Therefore, we cannot agree with these findings of these authors, since our results are radically different and few conclusions can be drawn from a single, uncontrolled study. 
In summary, endoscopic resection of carcinoid tumors in the digestive tract is a valid alternative in the treatment of these lesions. Moreover, this technique must be supported by EUS, since this is the most precise diagnostic technique for evaluating tumor size, and the best suited method for showing the tumor-free state of the muscularis propria. These two factors seem to condition the possibility of distant metastasis. Obviously, it is vital that distant tumor spread be ruled out before proceeding with the resection procedure.

\section{REFERENCES}

1. Hemminki K, Li X. Incidence trends and risk factors of carcinoid tumors: a nationwide epidemiologic study from Sweden. Cancer 2001; 92 (8): 2204-10

2. Modlin IM, Sandor A. An analysis of 8305 cases of carcinoid tumors. Cancer 1997; 79 (4): 813-29.

3. Ballantyne GH, Savoca PE, Flannery JT, Ahlman MH, Modlin IM. Incidence and mortality of carcinoids of the colon. Data from the Connecticut Tumor Registry. Cancer 1992; 69 (10): 2400-5.

4. Higaki S, Nishiaki M, Mitani N, Yanai H, Tada M, Okita K. Effectiveness of local endoscopic resection of rectal carcinoid tumors. Endoscopy 1997; 29 (3): 171-5.

5. Koura AN, Giacco GG, Curley SA, Skibber JM, Feig BW, Ellis LM. Carcinoid tumors of the rectum: effect of size, histopathology, and surgical treatment on metastasis free survival. Cancer 1997; 79 (7): 1294-8.

6. Yoshida M, Tsukamoto Y, Niwa Y, Goto H, Hase S, Hayakawa T, et al. Endoscopic assessment of invasion of colorectal tumors with a new high-frequency ultrasound probe. Gastrointest Endosc 1995; 41 (6): 587-92.

7. Mani S, Modlin IM, Ballantyne G, Ahlman H, West B. Carcinoids of the rectum. J Am Coll Surg 1994; 179 (2): 231-48.

8. Kulke MH, Mayer RJ. Carcinoid tumors. N Engl J Med 1999; 340 (11): 858-68.

9. Arguello L, Pellise M, Miquel R. Utility of echoendoscopy in the evaluation of submucosal tumors and extrinsic compressions of the digestive tract. Gastroenterol Hepatol 2002; 25 (1): 13-8.

10. Miettinen M, Lasota J. Gastrointestinal stromal tumors-definition, clinical, histological, immunohistochemical, and molecular genetic features and differential diagnosis. Virchows Arch 2001; 438 (1): 112.

11. Chak A. EUS in submucosal tumors. Gastrointest Endosc 2002; 56 (Supl. 4): S43-8.

12. Catalano MF. Endoscopic ultrasonography in the diagnosis of submucosal tumors: need for biopsy. Endoscopy 1994; 26 (9): 788-91.

13. Giovannini M, Seitz JF, Monges G, Perrier H, Rabbia I. Fine-needle aspiration cytology guided by endoscopic ultrasonography: results in 141 patients. Endoscopy 1995; 27 (2): 171-7.

14. Gu M, Ghafari S, Nguyen PT, Lin F. Cytologic diagnosis of gastrointestinal stromal tumors of the stomach by endoscopic ultrasoundguided fine-needle aspiration biopsy: cytomorphologic and immunohistochemical study of 12 cases. Diagn Cytopathol 2001; 25 (6): 343-50.

15. Wiersema MJ, Vilmann P, Giovannini M, Chang KJ, Wiersema LM. Endosonography-guided fine-needle aspiration biopsy: diagnostic accuracy and complication assessment. Gastroenterology 1997; 112 (4): 1087-95.

16. Dodd LG, Nelson RC, Mooney EE, Gottfried M. Fine-needle aspiration of gastrointestinal stromal tumors. Am J Clin Pathol 1998; 109 (4): 439-43.

17. Brainard JA, Goldblum JR. Stromal tumors of the jejunum and ileum: a clinicopathologic study of 39 cases. Am J Surg Pathol 1997; 21 (4): 407-16.

18. Waxman I, Saitoh Y, Raju GS, Watari J, Yokota K, Reeves AL, et al. High-frequency probe EUS-assisted endoscopic mucosal resection: a therapeutic strategy for submucosal tumors of the GI tract. Gastrointest Endosc 2002; 55 (1): 44-9.
19. Kawamoto K, Yamada Y, Furukawa N, Utsunomiya T, Haraguchi Y, Mizuguchi M, et al. Endoscopic submucosal tumorectomy for gastrointestinal submucosal tumors restricted to the submucosa: a new form of endoscopic minimal surgery. Gastrointest Endosc 1997; 46 (4): $311-7$.

20. Kojima T, Takahashi H, Parra-Blanco A, Kohsen K, Fujita R. Diagnosis of submucosal tumor of the upper GI tract by endoscopic resection. Gastrointest Endosc 1999; 50 (4): 516-22.

21. Hyun JH, Jeen YT, Chun HJ, Lee HS, Lee SW, Song CW, et al. Endoscopic resection of submucosal tumor of the esophagus: results in 62 patients. Endoscopy 1997; 29 (3): 165-70.

22. Wei SC, Wong JM, Shieh MJ, Sun CT, Wang CY, Wang TH. Endoscopic resection of gastrointestinal submucosal tumors. Hepatogastroenterology 1998; 45 (19): 114-8.

23. Hunt GC, Smith PP, Faigel DO. Yield of tissue sampling for submucosal lesions evaluated by EUS. Gastrointest Endosc 2003; 57 (1): 68-72.

24. Palazzo M, Rouseau G. Écho-endoscopie digestive. Paris: Masson; 1998: 21-7.

25. Shen EF, Arnott ID, Plevris J, Penman ID. Endoscopic ultrasonography in the diagnosis and management of suspected upper gastrointestinal submucosal tumours. Br J Surg 2002; 89 (2): 2315 .

26. Palazzo L, Landi B, Cellier C, Cuillerier E, Roseau G, Barbier JP. Endosonographic features predictive of benign and malignant gastrointestinal stromal cell tumours. Gut 2000; 46 (1): 88-92.

27. Rosch T. Endoscopic ultrasonography in upper gastrointestinal submucosal tumors: a literature review. Gastrointest Endosc Clin N Am 1995; 5 (3): 609-14.

28. Rosch T, Kapfer B, Will U, Baronius W, Strobel M, Lorenz R, et al. German EUS Club. Endoscopic ultrasonography. Accuracy of endoscopic ultrasonography in upper gastrointestinal submucosal lesions: a prospective multicenter study. Scand J Gastroenterol 2002; 37 (7): 856-62.

29. Brand B, Oesterhelweg L, Binmoeller KF, Sriram PV, Bohnacker S, Seewald $\mathrm{S}$, et al. Impact of endoscopic ultrasound for evaluation of submucosal lesions in gastrointestinal tract. Dig Liver Dis 2002; 34 (4): $290-7$.

30. Souquet JC, Bobichon R. Role of endoscopic ultrasound in the management of the submucosal tumors in the esophagus and the stomach. Acta Endoscop 1996; 26: 307-12.

31. Gress F, Schmitt C, Savides T, Faigel DO, Catalano M, Wassef $\mathrm{W}$, et al. Interobserver agreement for EUS in the evaluation and diagnosis of submucosal masses. Gastrointest Endosc 2001; 53 (1): 71-6.

32. Takada N, Higashino M, Osugi H, Tokuhara T, Kinoshita H. Utility of endoscopic ultrasonography in assessing the indications for endoscopic surgery of submucosal esophageal tumors. Surg Endosc 1999; 13 (3): 228-30.

33. Kameyama H, Niwa Y, Arisawa T, Goto H, Hayakawa T. Endoscopic ultrasonography in the diagnosis of submucosal lesions of the large intestine. Gastrointest Endosc 1997; 46 (5): 406-11.

34. Geller A, Wang KK, DiMagno EP. Diagnosis of foregut duplication cysts by endoscopic ultrasono-graphy. Gastroenterology 1995; 109 (3): 838-42.

35. Bhutani MS, Hoffman BJ, Reed C. Endosonographic diagnosis of an esophageal duplication cyst. Endoscopy 1996; 28 (4): 396-7.

36. Palazzo L, Landi B, Cellier C, Roseau G, Chaussade S, Couturier D, et al. Endosonographic features of esophageal granular cell tumors. Endoscopy 1997; 29 (9): 850-3.

37. Hizawa K, Iwai K, Esaki M, Suekane H, Inuzuka S, Matsumoto T, et al. Endosonographic features of Brunner's gland hamartomas which were subsequently resected endoscopically. Endoscopy 2002; 34 (12): 956-8.

38. Chak A, Canto MI, Rosch T, Dittler HJ, Hawes RH, Tio TL, et al. Endosonographic differentiation of benign and malignant stromal cell tumors. Gastrointest Endosc 1997; 45 (6): 468-73.

39. Higaki S, Nishiaki M, Mitani N, Yanai H, Tada M, Okita K. Effectiveness of local endoscopic resection of rectal carcinoid tumors. Endoscopy 1997; 29 (3): 171-5.

40. Imada-Shirakata Y, Sakai M, Kajiyama T, Kin G, Inoue K, Torii A, et al. Endoscopic resection of rectal carcinoid tumors using aspiration lumpectomy. Endoscopy 1997; 29 (1): 34-8. 
41. Oshitani N, Hamasaki N, Sawa Y, Hara J, Nakamura S, Matsumoto T, et al. Endoscopic resection of small rectal carcinoid tumours using an aspiration method with a transparent overcap. J Int Med Res 2000; 28 (5): 241-6.

42. Nishimori I, Morita M, Sano S, Kino-Ohsaki J, Kohsaki T, Suenaga $\mathrm{K}$, et al. Endosonography-guided endoscopic resection of duodenal carcinoid tumor. Endoscopy 1997; 29 (3): 214-7.

43. Lachter J, Chemtob J. EUS may have limited impact on the endoscopic management of gastric carcinoids. Int J Gastrointest Cancer 2002; 31 (1-3): 181-3.

44. Yoshikane H, Suzuki T, Yoshioka N, Ogawa Y, Hamajima E, Hasegawa N, et al. Duodenal carcinoid tumor: endosonographic imaging and endoscopic resection. Am J Gastroenterol 1995; 90 (4) $642-4$
45. Akahoshi K, Fujimaru T, Nakanishi K, Harada N, Nawata H. Endosonography probe-guided endoscopic resection of small flat rectal carcinoid tumor using band ligation technique. Endoscopy 2001; 33 (5): 471.

46. Vázquez-Iglesias JL, Souto Ruzo J. A new technique for endoscopic resection of rectal carcinoid tumors. Digestion 1998; 59 (Supl. 3): 542 .

47. Kajiyama T, Hajiro K, Sakai M, Inoue K, Konishi Y, Takakuwa H, et al. Endoscopic resection of gastrointestinal submucosal lesions: a comparison between strip biopsy and aspiration lumpectomy. Gastrointest Endosc 1996; 44 (4): 404-10.

48. Ono A, Fujii T, Saito Y, Matsuda T, Lee DT, Gotoda T, Saito D. Endoscopic submucosal resection of rectal carcinoid tumors with a ligation device. Gastrointest Endosc 2003; 57 (4): 583-7.

\title{
Resección endoscópica asistida por ecoendoscopia de tumores carcinoides del aparato digestivo
}

\author{
D. Martínez-Ares, J. Souto-Ruzo, M. J. Varas Lorenzo¹, J. C. Espinós Pérez'1, J. Yáñez López, R. Abad Belando' \\ P. A. Alonso Aguirre, J. M. Miquel Colell ${ }^{1}$ y J. L. Vázquez Iglesias
}

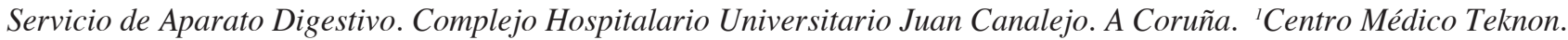
Barcelona

\section{RESUMEN}

Introducción: los carcinoides son los tumores neuroendocrinos más frecuentes, representado el tracto digestivo una de sus localizaciones más habituales. La mayoría de las lesiones se localizan en áreas poco accesibles para la endoscopia convencional (intestino delgado y apéndice); los carcinoides localizados en el tracto gastroduodenal y en el intestino grueso pueden ser estudiados endoscópicamente; en estos casos, si se confirma una enfermedad localizada, el tratamiento local mediante resección endoscópica puede ser el tratamiento de elección. Dado que la ecoendoscopia se ha mostrado como la técnica de elección en el estudio de los tumores de crecimiento submucoso, la selección de los pacientes candidatos a una resección local segura y efectiva ha de basarse en esta técnica.

Pacientes y método: se han seleccionado los pacientes con tumores carcinoides digestivos tratados endoscópicamente entre 1997 y 2002 . Se consideraron subsidiarios de resección endoscópica aquellos pacientes con tumores menores de $10 \mathrm{~mm}$, que respetan la muscular propia y con un estudio de extensión negativo. Los objetivos finales del estudio fueron la evaluación de la eficacia (resección completa) y seguridad (complicaciones) de la técnica. El seguimiento consistió en biopsias de la escara al mes y los 12 meses de la resección.

Resultados: en el periodo referido hemos resecado endoscópicamente 24 tumores en 21 pacientes (edad media de 51,7 años; $71,5 \%$ varones). Las lesiones eran en su mayoría hallazgos incidentales en exploraciones indicadas por otros motivos. La resección se indicó en la mayoría de los casos por sospecha ecoendoscópica de tumor carcinoide. La ecoendoscopia además permitió establecer con claridad la capa de origen de la lesión y el tamaño de la misma. La extirpación se llevó a cabo en 13 casos (54,2\%) mediante la técnica convencional de polipectomía con asa, en 9 casos $(37,5 \%)$ asistida con inyección submucosa de suero salino y/o adrenalina y en 2 casos $(8,3 \%)$ tras ligar la lesión con bandas elásticas. En todos los casos la resección fue completa, sin recidivas durante el seguimiento. En un único caso se produjo una complicación mayor: una hemorragia postpolipectomía que se controló endoscópicamente.

Conclusiones: la resección endoscópica de los tumores carcinoides, en pacientes bien seleccionados, es una técnica segura y eficaz permitiendo una resección completa en todos los casos con escasas complicaciones. La ecoendoscopia es la técnica de elección para seleccionar los pacientes candidatos a resección endoscópica.

Palabras clave: Tumores carcinoides. Tratamiento. Resección endoscópica. Complicaciones. Ultrasonografía endoscópica.

\section{INTRODUCCIÓN}

El carcinoide es el tumor neuroendocrino más frecuente (1), con una incidencia de 2-2,4 casos por 100.000 habitantes y año, asentando el $74 \%$ de ellos en el tubo digestivo (2); su localización más frecuente es el intestino delgado y el apéndice $(1,2)$, siendo el apendicular el que tiene un mejor pronóstico (2). 
Tan sólo los tumores localizados en el área gastroduodenal $(3 \%$ del total) y en colon y recto $(10$ y $11 \%$ respectivamente) son accesibles para el estudio endoscópico (2) y sólo se contemplaría la resección local en los casos de enfermedad localizada. Así, los carcinoides gástricos tipo 1 y 2 menores de $10 \mathrm{~mm}$ de diámetro (menos de un $2 \%$ presentan metástasis) pueden ser extirpados endoscópicamente. Por el contrario, los tumores de colon, habitualmente del colon derecho y poco sintomáticos, se diagnostican en fases más avanzadas (3). En el recto, hasta un $85 \%$ de los tumores están localizados en el momento del diagnóstico ya que suelen ser hallazgos incidentales. Con un tamaño inferior a $1 \mathrm{~cm}$, al igual que los gástricos, menos de un $2 \%$ presentan enfermedad metastásica, lo que contrasta con un $60-80 \%$ de los mayores de $2 \mathrm{~cm}(4,5)$. Además, cuando la ultrasonografía endoscópica (USE) pone de manifiesto la indemnidad de la muscular propia $(4,6)$, se puede realizar con gran seguridad y eficacia un tratamiento local. Cuando el tamaño del tumor se encuentra entre 1 y $2 \mathrm{~cm}$, la decisión terapéutica puede ser controvertida. Se estima que el $10-15 \%$ de los tumores presentarán metástasis (7), por lo que el tratamiento de elección dependerá del riesgo quirúrgico del paciente. Sólo en pacientes con riesgo no asumible se realizará tratamiento local (8).

Los carcinoides son tumores submucosos con crecimiento en cualquiera de las capas de la pared del tubo digestivo por debajo de una mucosa indemne (9) y con origen en las células del estroma gastrointestinal (10). En su mayoría representan hallazgos incidentales en exploraciones indicadas por otros motivos (11). En los tumores submucosos, la endoscopia convencional tiene grandes limitaciones diagnósticas ya que la biopsia endoscópica rara vez resulta concluyente $(9,11,12)$. Adicionalmente, la citología tomada por punción aspirativa con aguja fina (PAAF) de estas lesiones no presenta una gran rentabilidad (11,13-16). Además, el diagnóstico de malignidad se basa en una serie de parámetros muchos de los cuales sólo se pueden estudiar en la pieza de resección (17).

La resección endoscópica de los tumores submucosos se ha mostrado como una técnica segura y eficaz (18-22) y claramente superior a la biopsia endoscópica en el diagnóstico de los mismos (23). Teniendo en cuenta que su extirpación es la forma más adecuada de alcanzar el diagnóstico en este tipo de lesiones, esta habrá de llevarse a cabo siempre que la lesión alcance gran tamaño o presente un crecimiento significativo, siempre que se complique con clínica obstructiva o hemorrágica y siempre que existan dudas diagnósticas $(11,24)$.

La USE es la técnica de elección en el estudio previo a la resección de estas lesiones $(11,25,26)$. En efecto, permite diferenciar con precisión los tumores submucosos de las compresiones extrínsecas $(11,19,29-31)$, las masas sólidas de las quísticas (9), evalúa con gran exactitud la capa de origen del tumor $(24,32)$ y el tamaño del mismo (27). Además, puede establecer preoperatoriamente el tipo de lesión del que se trata $(11,24,33-37)$ y se ha mostrado muy segura en la predicción del comportamiento maligno de la misma $(26,28,29,38)$.

A continuación presentamos nuestros resultados en la resección endoscópica de tumores carcinoides asistida por
USE. El objetivo de este trabajo es mostrar cómo la USE permite la selección de los pacientes que se benefician del tratamiento local, ya que al valorar adecuadamente el tamaño y la capa de origen del tumor permite una resección completa y segura en la mayoría de los casos.

\section{PACIENTES Y MÉTODO}

\section{Selección de pacientes}

Han sido seleccionados los pacientes que entre el 1 de enero de 1997 y el 31 de diciembre de 2002 les fueron resecados endoscópicamente tumores carcinoides del tubo digestivo en el Hospital Juan Canalejo de La Coruña, y en el Centro Médico Teknon, de Barcelona. Los pacientes han sido seguidos de forma prospectiva y se han incluido sólo aquellos que tienen un seguimiento mínimo de 12 meses.

\section{Metodología}

A todos los pacientes en quienes se identificó una lesión submucosa digestiva se les realizó un estudio ecoendoscópico mediante el ecogastroscopio radial Olympus GF-UM 160 y el ecocolonoscopio Olympus CF-UM 20. Cuando dicha exploración definió una lesión que fue considerada subsidiaria de resección por vía endoscópica, esta fue realizada mediante los gastroscopios Olympus GIF-100 y Olympus GIF 120 o el colonoscopio Olympus GIF 100. La resección se efectuó con asa de polipectomía, utilizándose tres técnicas distintas: la técnica convencional de resección con asa de polipectomía, una resección asistida con inyección submucosa de suero salino fisiológico y/o adrenalina diluida, o una resección asistida con la colocación de bandas elásticas para asegurar una correcta elevación de la lesión. Antes de proceder a la resección se llevó a cabo un estudio de extensión mediante una tomografía axial computerizada abdóminopélvica, determinación del ácido hidroxiindolacético en orina o una gammagrafía con octreóctida.

Fueron considerados subsidiarios de resección endoscópica aquellos pacientes con tumores menores de $1 \mathrm{~cm}$, en los que la ecoendoscopia mostraba la indemnidad de la cuarta capa (muscular propia) y con un estudio de extensión que descartase enfermedad a distancia. Algunos pacientes con excesivo riesgo quirúrgico que presentaban tumores de mayor tamaño, aunque con enfermedad localizada, también fueron tratados mediante resección endoscópica. Finalmente, tras la resección se programó un seguimiento consistente en biopsias de la escara al mes y a los doce meses de la extirpación de los tumores.

\section{Variables estudiadas}

Al margen de los datos demográficos de los pacientes, se han incluido en el estudio todas las variables relacionadas con las características endoscópicas y ecoendoscópicas de las lesiones (tamaño, morfología, aspecto de los bordes, 
ecogenicidad, presencia de áreas quísticas o focos hiperecogénicos, presencia de adenopatías, ulceración y capa en la que se localizaban los tumores). Asimismo, estudiamos con detalle la localización de las lesiones, las manifestaciones clínicas derivadas de las mismas, los motivos por los que se indicó la resección de las lesiones y la técnica empleada para ello. Como es lógico, el objetivo principal del estudio fue el de evaluar la eficacia de la resección endoscópica de los tumores submucosos (resección completa) y la seguridad de la misma (presencia de complicaciones y tipo de complicaciones). El análisis estadístico se llevó a cabo mediante el paquete estadístico del SPSS 11.5 para Windows.

\section{RESULTADOS}

En el tiempo que duró este estudio han sido tratados endoscópicamente 24 tumores carcinoides hallados en 21 pacientes (19 pacientes con tumores únicos y 2 con tumores multicéntricos). La edad media fue de 51,76 años (rango de 31 a 73 años) y se trataba mayoritariamente de pacientes varones $(71,5 \%)$.

Las lesiones se localizaron principalmente en la cavidad gástrica $(41,7 \%)$ y en el recto $(41,7 \%)$. El resto de las lesiones fueron duodenales $(16,6 \%)$. En la mayoría de los casos $(71,5 \%)$, los tumores fueron hallazgos incidentales en exploraciones indicadas por otros motivos (Tabla I).

El tamaño medio de las lesiones medido por endoscopia convencional fue de $8 \mathrm{~mm}$, significativamente menor $(\mathrm{p}=$ $0,02)$ que el tamaño de la pieza de resección $(9 \mathrm{~mm})$. Sin embargo, el tamaño medido apreciado mediante la USE fue de $8,95 \mathrm{~mm}$, sin diferencias significativas en relación con el tamaño medido por el patólogo ( $\mathrm{p}=0,25)$. El 83,2\% de las lesiones (20 tumores) eran menores de $10 \mathrm{~mm}, 3$ lesiones tenían un tamaño de entre 10 y $20 \mathrm{~mm}$ y sólo 1 tenía un tamaño mayor de $20 \mathrm{~mm}$. En todos los casos, el estudio de extensión fue negativo y en los pacientes con lesiones superiores a $10 \mathrm{~mm}$ el riesgo quirúrgico por enfermedades asociadas era excesivamente elevado.

En todos los casos se trataba de lesiones dependientes de la muscular de la mucosa, de bordes regulares, hipoecogénicas y con un patrón ecográfico homogéneo (Fig. 1). En un único caso el tumor estaba ulcerado, siendo causa de hemorragia digestiva. La resección de las lesiones submucosas fue indicada en 18 casos (75\%) por una sospecha ultrasonográfica de tumor carcinoide, en 5 casos $(20,8 \%)$ por biopsias sugestivas de malignidad y en 1 caso por el sangrado derivado del tumor (Tabla I).

La resección se llevó a cabo en 13 casos $(54,2 \%)$ mediante la técnica convencional de polipectomía con asa; en 9 casos $(37,5 \%)$ se realizó previamente una inyección submucosa de suero salino fisiológico y/o adrenalina para conseguir una mayor elevación de la lesión; finalmente, en 2 casos $(8,3 \%)$ se realizó la resección tras ligar la lesión con bandas elásticas (Fig. 2). En estos últimos casos se trataba de lesiones muy pequeñas, de 5 y $6 \mathrm{~mm}$, que no se conseguían elevar de forma satisfactoria con la inyección submucosa.

En todos los casos la resección fue completa como se documentó tras el examen de la pieza de resección, que mostró
Tabla I

\begin{tabular}{|c|c|}
\hline Variables & $\begin{array}{c}\text { Número de paciente } \\
(\%)\end{array}$ \\
\hline Pacientes & 21 \\
\hline Tumores resecados & 24 \\
\hline Pacientes con tumores multicéntricos & $2(9,5 \%)$ \\
\hline $\begin{array}{l}\text { Distribución por sexos } \\
\text { Varones } \\
\text { Mujeres }\end{array}$ & $\begin{array}{r}15(71,5 \%) \\
6(28,5 \%)\end{array}$ \\
\hline $\begin{array}{l}\text { Localización de las lesiones } \\
\text { Estómago } \\
\text { Recto } \\
\text { Duodeno }\end{array}$ & $\begin{array}{r}10(41,7 \%) \\
10(41,7 \%) \\
4(16,6 \%)\end{array}$ \\
\hline $\begin{array}{l}\text { Tamaño de las lesiones } \\
\qquad 10 \mathrm{~mm} \\
\quad 10-20 \mathrm{~mm} \\
>20 \mathrm{~mm}\end{array}$ & $\begin{array}{c}20(83,2 \%) \\
3(12,6 \%) \\
1(4,2 \%)\end{array}$ \\
\hline $\begin{array}{l}\text { Manifestaciones clínicas } \\
\text { Dispepsia } \\
\text { Hemorragia digestiva alta } \\
\text { Hemorragia digestiva baja } \\
\text { Anemia } \\
\text { Hallazgo incidental }\end{array}$ & $\begin{array}{c}2(9,4 \%) \\
1(4,7 \%) \\
1(4,7 \%) \\
2(4,7 \%) \\
15(71,5 \%)\end{array}$ \\
\hline $\begin{array}{l}\text { Indicaciones de la resección } \\
\text { Biopsias de malignidad } \\
\text { Sospecha de carcinoide } \\
\text { Hemorragia }\end{array}$ & $\begin{array}{c}5(20,8 \%) \\
18(75 \%) \\
1(4,2 \%)\end{array}$ \\
\hline $\begin{array}{l}\text { Técnica de resección } \\
\text { Polipectomía con inyección submucosa } \\
\text { Polipectomía convencional con asa } \\
\text { Polipectomía asistida con bandas }\end{array}$ & $\begin{aligned} & 9(37,5 \%) \\
& 13(54,2 \%) \\
& 2(8,3 \%)\end{aligned}$ \\
\hline Resección completa & $24(100 \%)$ \\
\hline $\begin{array}{c}\text { Complicaciones } \\
\text { Hemorragia } \\
\text { Perforación }\end{array}$ & $\begin{array}{l}1(4,2 \%) \\
0\end{array}$ \\
\hline
\end{tabular}

que los bordes de resección estaban libres de tumor; además, las biopsias de la escara realizadas a los 30 días y a los 12 meses descartaron en todos los casos una recidiva local. Únicamente se registró una complicación mayor: un sangrado importante que fue controlado endoscópicamente. El paciente fue ingresado para vigilancia, aunque no precisó trasfusión sanguínea.

\section{DISCUSIÓN}

La resección endoscópica de los tumores carcinoides no es novedosa ya que se viene realizando desde principios de los años noventa. Higaki y cols. (39) publicaron en 1997 una serie de 22 carcinoides rectales, 18 de los cuales fueron resecados endoscópicamente. Mostraron que cuando el tumor era inferior a $10 \mathrm{~mm}$ y no invadía más allá de la submucosa (muscular propia indemne), el riesgo de enfermedad a distancia era mínimo, por lo que en estos casos la resección local por vía endoscópica es una alternativa válida. Nosotros 
hemos seguido estos criterios para indicar la resección endoscópica de lesiones de esta naturaleza: lesiones de un tamaño inferior a los $10 \mathrm{~mm}$, con estudio de extensión negativo y con la capa muscular propia respetada. Fueron resecadas endoscópicamente únicamente cuatro lesiones de tamaño superior; en todos ellos, el estudio de extensión fue negativo, pero el elevado riesgo quirúrgico de los pacientes hacía de la resección local la actitud más adecuada. A las mismas conclusiones llegaron Imada-Shirakata y cols. (40) ese mismo año y, más recientemente, Oshitani y cols. (41) aunque con unas series de sólo 8 y 7 pacientes respectivamente. Al igual que en el resto de los tumores submucosos, la ecoendoscopia puede establecer con gran precisión tanto el tamaño del tumor como la capa de la pared en la que se localiza la lesión $(26,27,32)$. En nuestra experiencia, la ecoendoscopia permite establecer con éxito la capa de origen en todos los casos y valorar también de forma muy precisa del tamaño del tumor. Por el contrario, la endoscopia convencional subestima el tamaño de la lesión, ya que sólo puede valorar el crecimiento intraluminal de la misma.

Desde el punto de vista ultrasonográfico la morfología de los tumores carcinoides es muy similar a la de los leiomiomas: lesiones bien delimitadas, hipoecoicas y con una ecogenicidad homogénea, bordes regulares y asentando en las tres primeras capas de la pared (11). Por lo tanto, en muchos casos la resección de las lesiones es la única forma de alcanzar un diagnóstico. No obstante, la resección de lesiones submucosas por vía endoscópica presenta una tasa de complicaciones bien documentada, siendo la hemorragia la más frecuente. Su frecuencia oscila entre el 4,8 y el 16\% (20-23) y en todos los casos comunicados pudo ser resuelta endoscópicamente, sin precisarse intervención quirúrgica. En nuestra serie sólo se produjo una complicación mayor (1 caso de hemorragia controlada endoscópicamente); hay que tener en cuenta que prácticamente la totalidad de las lesiones estaban localizadas en la cavidad gástrica y en el recto, donde la frecuencia de las complicaciones es significativamente menor que en el colon derecho e incluso en el duodeno. La USE es la técnica más adecuada para valorar el tamaño tumoral, la localización exacta en el interior de la pared del tubo digestivo y aún para aventurar la naturaleza de la lesión. Adicionalmente, algunos autores han empleado además la USE para mostrar la correcta elevación de las lesiones tras la inyección submucosa de diversas sustancias (41). Por el contrario, Lachter y cols. (43) manifiestan que la ecoendoscopia puede tener un valor limitado ya que, en su experiencia, el estudio ecoendoscópico previo no excluye un seguimiento posterior y en todos los tumores que resecaron los márgenes de resección estaban infiltrados por el tumor. Sin embargo, su experiencia se reduce a tres tumores y en su trabajo mencionan otros aspectos importantes de la USE, como es su capacidad para excluir la presencia de estructuras vasculares próximas a la lesión que pudieran incrementar de forma notable el riesgo de hemorragia. En consecuencia, aún asumiendo la primera de sus afirmaciones, la segunda de ellas concedería un enorme valor a la resección endoscópica asistida por USE de los tumores submucosos.

Se han descrito distintas técnicas para proceder a la resección de los tumores carcinoides. Se puede realizar mediante la técnica convencional de polipectomía con asa, pero algunos autores prefieren realizar la resección tras elevar la lesión mediante la inyección submucosa de diversas sustancias, como podrían ser suero fisiológico, adrenalina diluida, etc. $(42,44)$. Otros autores han descrito la resección mediante una técnica consistente en la aspiración de la lesión dentro de un capuchón como los utilizados para la ligadura con bandas elásticas, lo que facilitaría el enlazar la lesión con el asa de polipectomía $(40,41)$. Se ha propuesto también la elevación de las lesiones mediante la ligadura con bandas elásticas para facilitar su extirpación con el asa de polipectomía (45-48). Kajiyama y cols. (47) afirman la utilización de un método de aspiración, ya sea la ligadura con bandas o el capuchón, es claramente más eficaz que el método de la strip-biopsy, alcanzándose el diagnóstico en un $95 \%$ de los casos frente al $77 \%$, y una resección completa de la lesión en el 87 frente al $74 \%$. Recientemente Ono y cols. (48) han publicado un estudio en el que comparan dos técnicas de resección. En una serie de 14 tumores carcinoides rectales resecados mediante una resección asistida con bandas elásticas, lograron una resección completa de la lesión en el $100 \%$ de los casos. Estos resultados fueron comparados con los obtenidos en una serie retrospectiva de 14 casos resecados mediante la técnica convencional de polipectomía con asa o mediante la técnica de mucusectomía, en la que en el $42 \%$ de los casos los márgenes de resección estaban afectos. Incluso en este grupo de pacientes había diferencias, ya que en el grupo de los pacientes sometidos a mucusectomía los márgenes quirúrgicos estaban afectos con menos frecuencia. Estos hallazgos difieren notablemente de los resultados de nuestra serie. Hemos empleado en 13 casos una técnica convencional de polipectomía con asa, en 9 una resección asistida con inyección submucosa de suero fisiológico y/o adrenalina diluida y en dos casos una resección asistida con bandas elásticas. En el 100\% de los casos la resección fue completa y en ningún caso se objetivaron recidivas locales ni a distancia de las lesiones (el estudio de extensión también había sido negativo). Por lo tanto, no podemos estar de acuerdo con lo afirmado por estos autores, ya que nuestros resultados son radicalmente distintos y tampoco se pueden sacar demasiadas conclusiones de un único estudio no controlado.

En resumen, la resección endoscópica de tumores carcinoides digestivos es una alternativa válida en el tratamiento de estas lesiones. Además, esta técnica debe apoyarse en la ecoendoscopia, ya que es esta la exploración más precisa para valorar el tamaño tumoral y la más adecuada para mostrar la indemnidad de la muscular propia, siendo estos dos los factores que parecen condicionar la posibilidad de metástasis a distancia. Como es obvio, antes de proceder a la resección es obligatorio el disponer de un estudio de extensión negativo. 